Shvets, A., Budanov, O., Koloskov, O., Nickolaenko, O., Shvets, O., \& Yampolsky, Yu. (2021). Evaluation of errors in estimating the azimuth of powerful lightning discharges from measurements of Q-bursts.

Ukrainian Antarctic Journal, 2, 48-57.

https://doi.org/10.33275/1727-7485.2.2021.677

A. Shvets ${ }^{1}$, O. Budanov ${ }^{2}$, O. Koloskov ${ }^{2,3}$, O. Nickolaenko ${ }^{1}$, O. Shvets ${ }^{1, *}$, Yu. Yampolsky ${ }^{2}$

${ }^{1}$ O.Ya. Usikov Institute for Radiophysics and Electronics of the National Academy

of Sciences of Ukraine, Kharkiv, 61085, Ukraine

${ }^{2}$ Institute of Radio Astronomy, National Academy of Sciences of Ukraine, Kharkiv, 61002, Ukraine

${ }^{3}$ State Institution National Antarctic Scientific Center, Ministry of Education and Science of Ukraine, Kyiv, 01601, Ukraine

* Corresponding author: 1xndrshvts9@gmail.com

\title{
Evaluation of errors in estimating the azimuth of powerful lightning discharges from measurements of Q-bursts
}

\begin{abstract}
In this work, we study the variability of errors in determining the azimuth of Q-bursts' sources on a daily time scale. Qbursts are electromagnetic pulse radiation in the extremely low frequency (ELF) range, excited by powerful lightning discharges, and they are used to locate lightnings over the world. We estimated the errors from data collected for two horizontal orthogonal magnetic field components of Q-bursts. Experimental records of Q-bursts were made at Akademik Vernadsky station from March to April 2019, which covers the vernal equinox day. We determined the azimuth of a Q-bursts' source by digital rotation of the coordinate system until the signal in one magnetic component would drop to its minimum value. The absolute value of the azimuth error was estimated from the ratio of the Q-burst's amplitude to the standard deviation of the residual signal. With an automated processing procedure, we analyzed over 800 thousand Q-bursts with amplitude over 10 picotesla. A characteristic diurnal pattern has been discovered in the estimated azimuth errors variations. The night level of the azimuth error exceeded the day level by about two degrees on average. The decrease-rise-decrease И-shaped swing during transition from night to day and mirror-symmetric $\mathrm{N}$ shaped swing during transition from day to night were identified. Each of those transitional swings takes about four hours. A comparison of the daily variations in the total intensity of ELF background noise with the estimated daily azimuth error diagrams demonstrates the opposite character: maximal level of the ELF background noise was observed during the daytime while the estimated azimuth errors take minimal values at this time. This contradicts the generally accepted notion that increasing the noise increases the error. Thus, we suppose that the residual magnetic component in a Q-burst occurs not only from the background noise but can also result from nonlinear polarization of the incident wave due to gyrotropy of the nighttime lower ionosphere. Coherent waves resulting from diffraction of the incident field on the day-night interface in the Earth-ionosphere cavity could explain the U- and N-shaped swings of the azimuth error during the passage of the solar terminator.
\end{abstract}

Keywords: Earth-ionosphere waveguide, extremely low frequency, lightning location, Q-burst

\section{Introduction}

Q-bursts are electromagnetic pulse radiation in the extremely low frequency (ELF) range, excited by strong lightning discharges (Ogawa \& Tanaka, 1970). The amplitude of Q-bursts exceeds the background ELF sig- nal five and more times, making it possible to analyze them as separate events. Direction finding of Q-bursts is used for location of high-power lightning discharges over the world by single-site (Burke \& Jones, 1992; Shvets et al., 2019) and multisite methods (Füllekrug \& Constable, 2000; Sato \& Fukunishi, 2003; Kolos- 
kov et al., 2004; Litvinenko \& Yampolsky, 2005; Sato et al., 2008).

A standard method of direction finding at ELF is based on the measurement of two orthogonal horizontal magnetic field components using induction coil antennas. Its accuracy depends on several factors. Direction-finding errors associated with the mismatch of the parameters of the two magnetic channels and the anisotropy of the underlying surface conductivity at the observation point are systematic and can be investigated and corrected for a particular observation point (Krider et al., 1976; Pessi et al., 2009; Bór et al., 2016).

The main reason for the deviations in the bearing of ELF burst sources is the presence of the Schumann resonance (SR) background signal in the experimental recordings. This continuous background is created by the totality of the world's thunderstorms (Nickolaenko \& Hayakawa, 2002). In measurements of bursts of ELF emissions, the ratio of the pulse signal amplitude to the root mean squared value of the background amplitude is usually in the range from 3 to 10 or higher, limiting the accuracy of bearing determination.

Among the natural reasons that complicate the direction finding of ELF radio emission sources, the literature most often mentions either the global inhomogeneity of the Earth-ionosphere resonator of the day-night type or the anisotropy of the ionospheric plasma. The Earth-ionosphere cavity is limited from below by the Earth's spherical surface and from above by the lower edge of the ionosphere. It is known that the conductivity of land is about $10^{-3} \mathrm{~S} / \mathrm{m}$ and very rarely decreases to $10^{-4} \mathrm{~S} / \mathrm{m}$. At the $\mathrm{SR}$ frequencies, the ionospheric plasma, the density of which rapidly increases with frequency, begins to influence radio signals, starting from an altitude where the conduction currents in the medium become equal to the displacement currents at a given frequency. At the fundamental SR frequency of $8 \mathrm{~Hz}$, this conductivity is $\sigma=0.44 \cdot 10^{-9} \mathrm{~S} / \mathrm{m}$, and it is reached about $55 \mathrm{~km}$ above the Earth's surface (Nickolaenko \& Hayakawa, 2002). Obviously, at SR frequencies, the Earth can be considered ideally conducting compared to the ionosphere. In other words, inhomogeneities of the ionosphere, not the Earth, play a decisive role in disturbances of ELF radio signals.
It should be noted that there are significant difficulties in constructing rigorous solutions and modeling the propagation of ELF radio waves in the Earthionosphere resonator with an anisotropic upper wall. The ionosphere can be considered an anisotropic medium, starting from an altitude of $80 \mathrm{~km}$. This means a significant complication of the task since the ionosphere is isotropic on the illuminated side of the Earth. Thus, it is inappropriate to take into account the anisotropy of the ionosphere in isolation from the day-night inhomogeneity. In works (Füllekrug et al., 1996; Füllekrug \& Sukhorukov, 1999; Nickolaenko et al., 2003; 2004; Bezrodny, 2007; Nickolaenko \& Sentman, 2007) it was shown that the anisotropy of the entire upper wall of the Earth-ionosphere resonator affects the polarization of SR signals. However, even in this case, the influence is so small that it is necessary to apply special measurement techniques to detect it. The anisotropy of the ionospheric plasma leads to subtle effects in the polarization coefficient of the horizontal magnetic field, but it does not manifest itself explicitly in the rest of the signal parameters (Nickolaenko \& Sentman, 2007).

The most noticeable inhomogeneity of the Earthionosphere resonator is the day-night inhomogeneity. Its influence was discussed in many works, but none of them directly compared observational and model data proving the effect of inhomogeneity. Modeling of propagation in an inhomogeneous resonator was carried out in works (Pechony \& Price, 2004; Yang \& Pasko, 2005; Pechony et al., 2007; Nickolaenko et al., 2018) it showed that the expected effects are small in magnitude, and special measurement techniques must be used to detect them.

In most published works, the influence of various inhomogeneities and anisotropy was considered purely speculative and often incorrectly. Often (e.g., Mlynarczyk et al., 2017), the problems of diffraction of ELF radio waves in an inhomogeneous resonator Earthionosphere are replaced by problems of refraction and reflection of plane waves from inhomogeneities. Such a replacement is incorrect already because the concept of a beam at ELF is inapplicable due to the gigantic size of the Fresnel zone. As a rule, the fact that the cylindrical wavefronts diverging from a point 


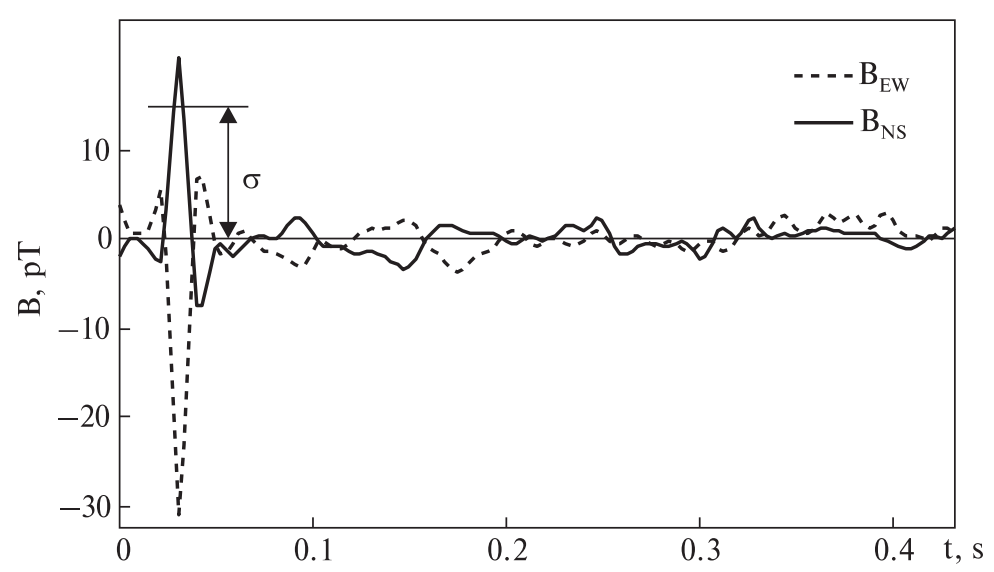

(a)

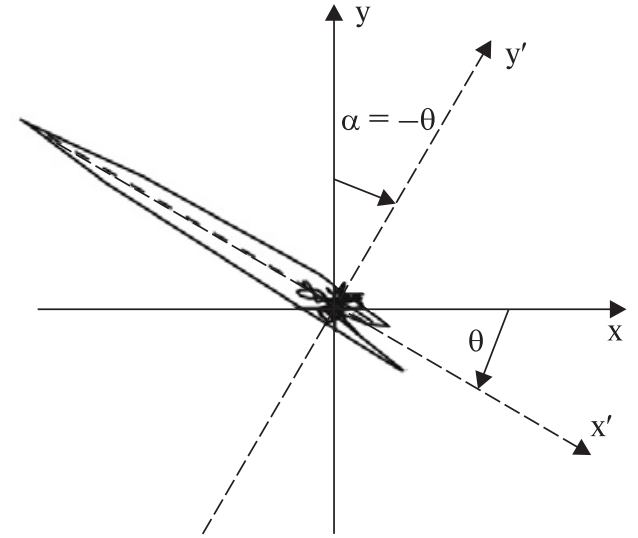

(b)

Figure 1. Waveforms of the $B_{N S}$ and $B_{E W}$ components (a) and hodograph (b) of the horizontal magnetic field of the Q-burst recorded at the Akademik Vernadsky station on March 26, 2019, at 23: 36: 17.066 UTC

source are observed in the experiment is also ignored, while plane waves are used for interpretation. The sphericity of the resonator is usually ignored.

In this paper, we describe the method and results of estimation of the azimuth errors of Q-burst sources. For the analysis, we use the experimental records of two horizontal magnetic field components of Qbursts measured at the Akademik Vernadsky station for the period covering the vernal equinox day, from March 11 to April 2, 2019.

\section{Data and methods}

\subsection{Data acquisition}

Measurements of the magnetic field in the ELF range are systematically carried out by the Institute of Radio Astronomy of the National Academy of Sciences of Ukraine (Koloskov et al., 2004; Litvinenko \& Yampolsky, 2005) at the Akademik Vernadsky station (65.2458 S, 64.2572 W). A two-channel magnetometer developed at the Lviv Center of Institute for Space Research of the National Academy of Sciences of Ukraine and the National Space Agency of Ukraine is used. The magnetometer consists of two inductive magnetic sensors with high permeability cores. The sensors are located $500 \mathrm{~m}$ from the main station buildings and $200 \mathrm{~m}$ from the so-called VLF hut with data collection equipment. Magnetic sensors are placed in the horizontal plane and oriented along with the meridional (magnetic component of $B_{N S}$ ) and perpendicular (magnetic component of $B_{E W}$ ) directions and constitute an orthogonal basis in the geographic coordinate system. The frequency band of the sensors at the $-3 \mathrm{~dB}$ level is $1-80 \mathrm{~Hz}$. The spectral density of noise in magnetic channels is less than $30 \mathrm{fT} / \mathrm{Hz}^{1 / 2}$. The mismatch between the transfer functions of the channels is less than $1 \%$ in amplitude and less than 1 degree in phase in the frequency band 4-55 Hz.

The signals from the magnetic sensors are transmitted via a cable to the data acquisition system, where a synchronous analog-to-digital conversion is performed with a resolution of 16 bits and a sampling rate of $320 \mathrm{~Hz}$. The data series are synchronized with absolute time using timestamps from the built-in GPS module. Continuous-time series of two orthogonal components of the horizontal magnetic field, calibrated in absolute magnetic induction units, are saved as daily files on a computer hard disk.

The amplitude of interference from the power mains, as a rule, significantly, and often many times, exceeds the level of the natural ELF signal. In processing, we used a compensation method to suppress $50 \mathrm{~Hz}$ interference (Shvets et al., 2003; Yatsevich et al., 2014) to avoid additional waveform distortions arising in the high-order notch filters (Yatsevich et al., 2014). After compensation of the $50 \mathrm{~Hz}$ interfer- 
ence, which falls within the working band of the ELF receiver, bursts with a given threshold amplitude were selected for further analysis.

\subsection{Methodology}

Figure 1a shows an example of Q-burst recorded at the Akademik Vernadsky station on March 26, 2019, at 23:36:17.066 UTC. For the analysis, we use the most powerful initial part of the Q-burst with a duration of about $20 \mathrm{~ms}( \pm 10 \mathrm{~ms}$ from the peak). This initial part of the Q-burst is formed by the direct wave propagating from lightning discharge to the observer along a short path in a spherical Earth-ionosphere cavity. Such a short segment makes it possible to exclude from the analysis the round-the-world wave at a distance to lightning up to $17-18 \mathrm{Mm}$. The hodograph of the Q-burst's horizontal magnetic field is shown in Figure 1b. Here, the Oy axis points North and the Ox one East.

The direction of arrival of a Q-burst is determined by minimizing the standard deviation $\sigma_{N S}$ in the $B_{N S}$ field component around the peak of the direct wave by rotating the coordinate system. The field components as a result of the rotation have the following form (the positive value of the angle $\theta$ is counted counterclockwise):

$$
\begin{gathered}
B^{\prime}{ }_{E W}=B_{E W} \cos \theta+B_{N S} \sin \theta \\
B_{N S}^{\prime}=-B_{E W} \sin \theta+B_{N S} \cos \theta .
\end{gathered}
$$

After minimizing $\sigma_{N S}$, in the rotated coordinate system, the components of the Q-burst field look as shown in Figure 2.

The dependence of the dispersion $\sigma_{N S}$, calculated around the peak of the direct Q-burst's wave in the $B_{N S}$ component, shown in Figure 1a, versus the rotation angle of the new coordinate system is presented in Figure 3.

The minimum value in this dependence corresponds to the orientation of the transverse field component along the $\mathrm{Ox}^{\prime}$ axis while the direction of wave arrival coincides with the Oy' axis in the rotated coordinate system. The source's azimuth is obviously equal to the angle of rotation of the axes in Figure 2b, taken with the opposite sign: $\alpha=-\phi_{\min }$. The positive

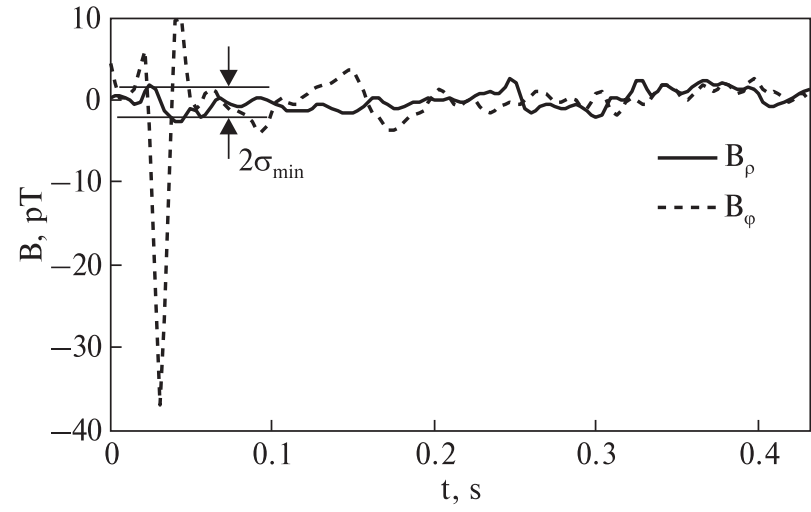

Figure 2. Magnetic field components of the Q-burst in the rotated coordinate system

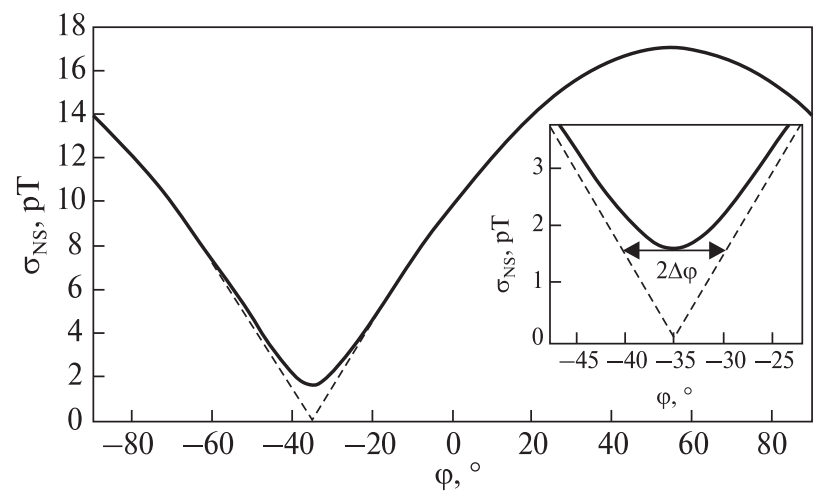

Figure 3. Dependence of the dispersion $\sigma_{N S}$, calculated around the peak of the direct Q-burst's wave in the $B_{N S}$ component, versus the rotation angle of the new coordinate system. The minimum in the dependence corresponds to the direction to the source in the right-handed coordinate system (Fig. 1b). The inset shows a plot of the dependence near the minimum

or negative direction of propagation along the $\mathrm{Oy}^{\prime}$ axis will be determined by the unknown polarity of the current in the lightning discharge, creating the ambiguity of 180 degrees.

In the case of linear polarization of the wave and the absence of background noise, this dependence is described by the modulus of the sine of the angle of rotation, shifted in phase by the angle corresponding to the minimum:

$$
\sigma_{N S}(\phi)=\sigma_{N S}^{\max }\left|\sin \left(\phi-\phi_{\min }\right)\right|,
$$

and at $\phi=\phi_{\min }$ it reaches zero. This dependence is shown in Figure 3 with a dotted line. 


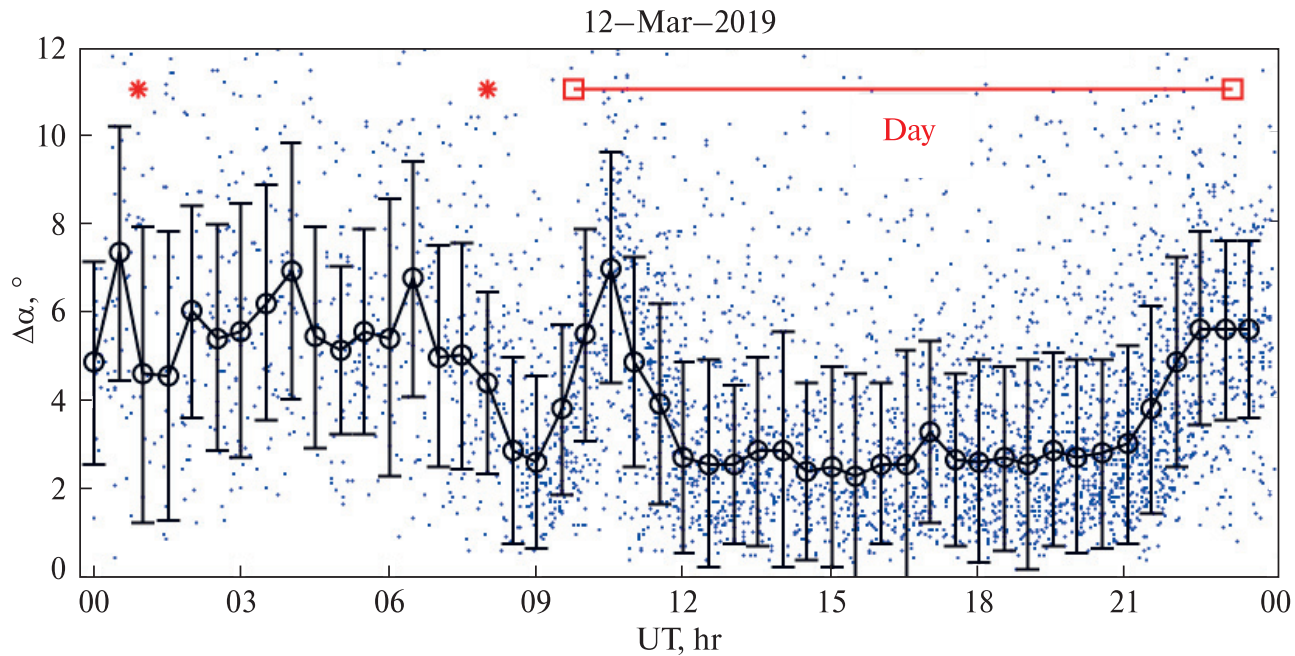

Figure 4. Scatter graph and median half-hour values of the estimated azimuth errors with the confidence intervals, calculated for Q-bursts with amplitude of more than $25 \mathrm{pT}$, recorded on March 12,2019

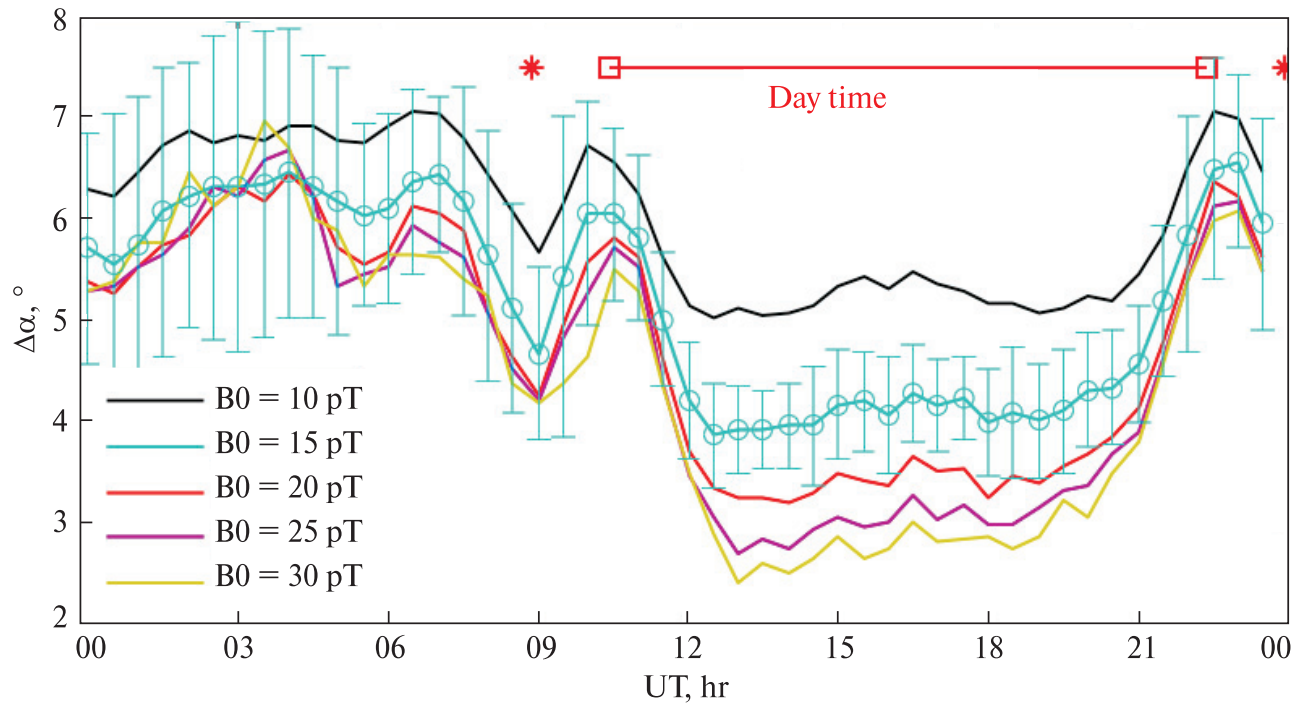

Figure 5. Average diurnal dependences of the estimated azimuth error calculated with different threshold amplitudes of Q-bursts. The moments of sunrise and sunset on the Earth's surface (squares) and at the $90 \mathrm{~km}$ altitude (asterisks) at the observation point are indicated for the middle of the measurement period from March 5 to April 2, 2019

The difference between the minimum value in the experimental dependence from zero is due to the background noise generated by lightning radiation coming from different directions and the difference in the polarization of the incident wave from the linear one. We estimate the maximum error in deter- mining the azimuth as the half-width of the theoretical dependence at the level of the minimum in the experimental dependence, as shown in the inset in Figure 3 . This value is approximately equal to the ratio of the dispersion of the residual signal in the $B_{N S}^{\prime}$ component to the dispersion of the signal in the 
transverse component of the $B_{E W}^{\prime}$ or, equivalently, the ratio of the minimum to the maximum value in the experimental dependence $\sigma_{N S}(\phi)$ :

$$
|\Delta \alpha|=|\Delta \phi| \cong \frac{\sigma_{N S}^{\min }}{\sigma_{N S}^{\max }} .
$$

In the above example of the Q-burst, the estimated azimuth error is: $\Delta \alpha= \pm 5.40^{\circ}$.

\section{Results}

A characteristic example of diurnal variations of the estimated azimuth error during March 12, 2019, is shown in Figure 4. We revealed 4255 Q-bursts with amplitude exceeding the threshold level $\mathrm{B} 0=25 \mathrm{pT}$ during this day. For each Q-burst, the azimuth error was estimated using the method described above. In Figure 4, dots form a scatter graph of the estimated azimuth errors of Q-bursts for this day. The solid line with circle markers shows changes in the median half-hour values of the estimated azimuth errors. Error bars show the standard deviations from the median values of the estimated azimuth errors. The moments of sunrise and sunset on the Earth's surface and $90 \mathrm{~km}$ above the observation point, which is essential for ELF propagation (Greifinger \& Greifinger, 1978), are marked with squares and asterisks, respectively. Daylight lasted from approximately 10:47 to 23:08 UT.

To analyze the influence of the background ELF signal, we calculated average diurnal variations of the estimated azimuth errors over the period from March 5 until April 2, 2019, covering the vernal equinox day. The data for March 18-23 were omitted in connection with the technical works on upgrading ELF equipment.

Shown in Figure 5 are the results of averaging the individual diurnal dependencies for the specified 21days period, obtained using the superposed epoch method. We calculated these dependencies for different values of the threshold level $\mathrm{B} 0$ from 10 to $30 \mathrm{pT}$, indicated on the graph legend. It is explainable that the mean level of the azimuth error increases with decreasing the threshold level. This is because we account for Q-bursts with smaller and smaller amplitudes making smaller the average amplitude of Qbursts relative to the level of the unchanged ELF

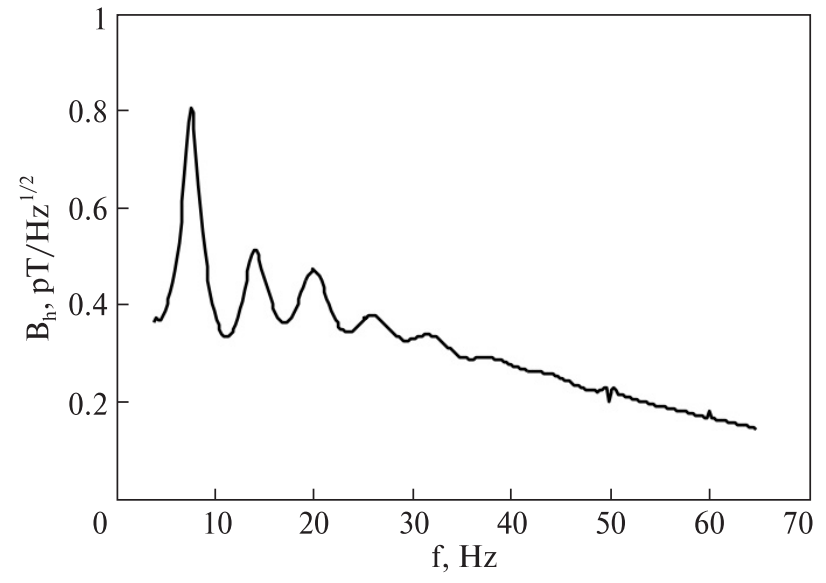

Figure 6. The spectrum of the background horizontal magnetic field averaged over the period from March 5 to April 2, 2019

background and, thus, decreasing the signal-to-noise ratio (SNR).

We can see that a certain daily pattern repeats on all plots, regardless of the threshold level of the Qbursts. The night level of the azimuth error exceeds the day level by about two degrees on average. One can also observe the decrease-rise-decrease $И$-shaped swing during transition from night to day and mirrorsymmetric $\mathrm{N}$-shaped swing during transition from day to night. Each of that transitional swings takes about four hours. We can also note more stable azimuth errors estimations during a day: the dispersion of the nighttime error estimates exceeds that during a daytime twice. The standard deviations shown with the error bars are given for only B $0=15 \mathrm{pT}$ curve for clarity of the graph, but similar deviations are also observed for the rest of the threshold values.

To interpret the observed diurnal pattern in the estimated azimuth errors, we consider the behavior of the ELF background signal, which is one of the major factors affecting the error in determining the azimuth of the arrival of Q-bursts.

The spectrum of the horizontal background field obtained by averaging the power spectra of sequential 10 second time realizations of the horizontal magnetic components over the entire period of analysis: $B_{h}(f)=\sqrt{\left\langle B_{E W}^{2}(f)\right\rangle+\left\langle B_{N S}^{2}(f)\right\rangle}$ is shown in Figure 6. One can see distinct peaks of SR, while at a frequency of $50 \mathrm{~Hz}$, only small residue resulting from the compen- 


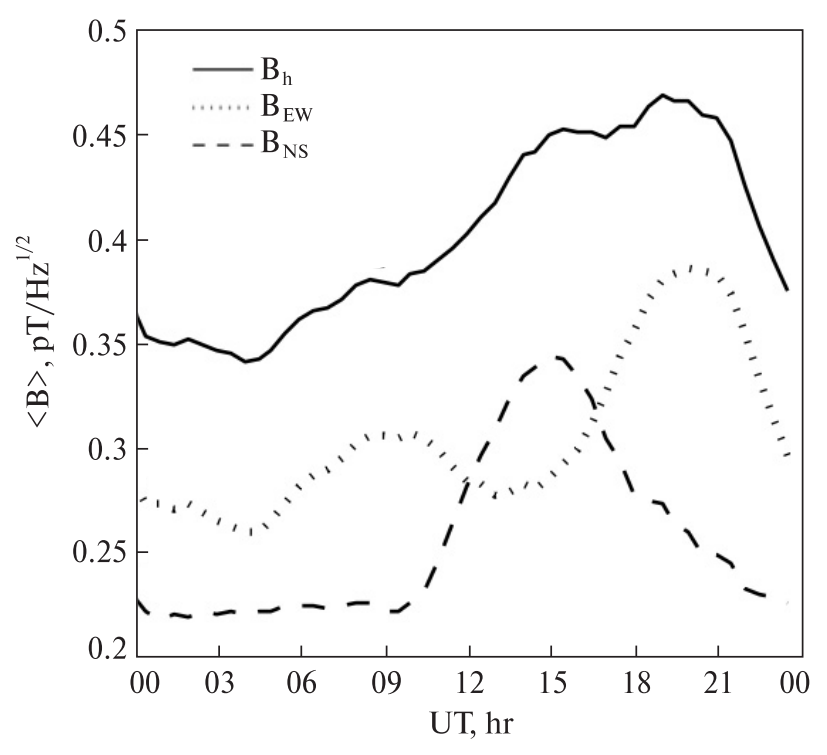

Figure 7. Diurnal dependences of the mean spectral density of the $<B_{N S}>$ and $<B_{E W}>$ components in the frequency band $4-65 \mathrm{~Hz}$

sation of the interference from the local power network is observed. A weak peak at $60 \mathrm{~Hz}$ appears to be the signal received from the electrical grids of the American continent (Koloskov \& Yampolsky, 2009). Thus, we conclude that the natural sources first and foremost produce the analyzed signal, while artificial interferences make up an insignificant proportion of it.

Next, we consider average diurnal variations of the intensities of the magnetic components $\left\langle B_{N S}\right\rangle$ and $\left\langle B_{E W}\right\rangle$ in the frequency band $4-65 \mathrm{~Hz}$. As shown in Figure 7, component $\left\langle B_{E W}\right\rangle$ demonstrates characteristic maxima at 9 and $21 \mathrm{UT}$, corresponding to the maximum thunderstorm activity in the Asian and South American world thunderstorm centers, respectively. The maximum in the $\left\langle B_{N S}\right\rangle$ component at about 15 hours answers the thunderstorm activity on the African continent. The total strength of the background horizontal magnetic field, shown in Figure 7a as a solid line, is calculated as follow:

$$
B_{h}=\sqrt{\left\langle B_{E W}^{2}\right\rangle+\left\langle B_{N S}^{2}\right\rangle} .
$$

We have shown above that the total level of the estimated azimuth errors increases with decreasing SNR. Comparison of the diurnal variations of $B_{h}$ in Figure 7 with the estimated azimuth errors diurnal patterns demonstrates the inverse character. The maximal intensity of $B_{h}$ is observed during the local daytime, while the estimated azimuth error diurnal pattern takes minimal values for this period.

\section{Discussion and conclusion}

Diurnal variations in the azimuth error of Q-burst sources were studied in several works. In the paper by Füllekrug and Sukhorukov (1999), based on the results of the analysis of Q-bursts recorded simultaneously at two remote observation points (Silberborn / Germany and Hollister / California), it was shown that during the local night, when the propagation path passed under the night ionosphere, the azimuth error increased from approximately 5 degrees during the local day to 15 degrees during the local night. The authors explain the discovered effect by the appearance of the magnetic field's longitudinal component due to the gyrotropy of the lower ionosphere. Determination of the ratio of the longitudinal and transverse components makes it possible to estimate the accuracy of direction finding and use this parameter to diagnose the effective height of the lower ionosphere.

The influence of the day-night heterogeneity on the deviation of the measured arrival azimuth was studied (Mlynarczyk et al., 2017). The maximum positive deviation of about 5 degrees from the azimuth determined from the data of the World Wide Lightning Location Network (WWLLN.net) occurred when the morning terminator passed over the observation point. The maximum deviation with the opposite sign occurred when the evening terminator passed. The authors explain this effect as a consequence of the refraction of ELF waves at the "day-night" boundary in the lower ionosphere.

Nickolaenko et al. (2018) modeled propagation with an inhomogeneous conductivity profile of the upper boundary of the Earth-ionosphere cavity. They demonstrated that a day-night inhomogeneity could lead to an error in determining the azimuth of no more than 3 degrees and concluded the experimentally observed azimuth deviations to be mainly related to the background signal of the Schumann resonance. 
The purpose of this work is to assess the influence of the background ELF signal on the errors in determining the azimuth of Q-burst sources. For the analysis, we used the experimental records of two orthogonal magnetic components of the ELF field made at the Akademik Vernadsky station in March-April 2019. We determined the azimuth of a Q-bursts' source by digital rotation of the coordinate system until the signal in one magnetic component would drop to its minimum value. The absolute value of the azimuth error was estimated from the ratio of the Q-burst's amplitude to the standard deviation of the residual signal. With an automated processing procedure, we analyzed over 800 thousand Q-bursts with amplitude larger than 10 picotesla.

We have found that the mean level of the azimuth error increases with decreasing the signal-to-noise ratio, defined as the ratio of the average amplitude of Q-bursts to the effective amplitude of the background ELF noise.

A characteristic diurnal pattern has been discovered in the estimated azimuth errors variations. The night level of the azimuth error exceeded the day level by about two degrees on average. The decrease-risedecrease $\boldsymbol{V}$-shaped swing during transition from night to day and mirror-symmetric $\mathrm{N}$-shaped swing during transition from day to night were identified. Each of those transitional swings takes about four hours. The estimated azimuth error level is about 6 degrees during the night, and it is on average about 3.5-4 degrees during the day. We can also note more stable azimuth errors estimations during a day: the dispersion of the nighttime error estimates exceeds that during a daytime twice. The $И$ - and $\mathrm{N}$-shaped swings in the diurnal dependences are strongly related in time with passages of the morning and evening terminators, and these features can be explained by interference between direct and coherent wave diffracted on the day-night interface in the Earth-ionosphere cavity (see Nickolaenko et al., 2018).

Comparison of the diurnal variations of the total intensity of the ELF background noise with the estimated azimuth errors diurnal patterns demonstrates the inverse character. Maximal level of the ELF background noise is observed during the local day, while the estimated azimuth error diurnal pattern takes minimal values for this period. This contradicts the generally accepted notion that increasing the noise increases the error. Thus, we should suppose that the residual magnetic component in a Q-burst occurs not only from the background noise but can also result in nonlinear polarization of the incident wave due to gyrotropy of the lower ionosphere boundary as was proposed by Füllekrug and Sukhorukov (1999).

Author contributions. ON: the idea, literature review, writing. AS: literature review. AS, OS: realization, algorithms, data processing and analysis, writing. OK, OB: data acquisition, preparation. YuY: validation, manuscript review, formal analysis and editing.

Acknowledgments. The authors express their gratitude to the State Institution National Antarctic Scientific Center, Ministry of Education and Science of Ukraine (http://uac.gov.ua) for partial funding in the framework of the research works (0121U112331, 0121U112293), and organizational and logistical support of these studies at the Akademik Vernadsky station. The topic of this study corresponds to the main scientific tasks of the departmental research works "Inversiya" (0117U004040) and "Yatagan-4" (0121U108635).

Conflict of Interest. The authors declare no conflict of interest.

\section{References}

Bezrodny, V. G. (2007). Magnetic polarization of the Schumann resonances: An asymptotic theory. Journal of Atmospheric and Solar-Terrestrial Physics, 69 (9), 995-1008. https:// doi.org/10.1016/j.jastp.2007.03.007

Bór, J., Ludván, B., Attila, N., \& Steinbach, P. (2016). Systematic deviations in source direction estimates of Q-bursts recorded at Nagycenk, Hungary. Journal of Geophysical Research: Atmospheres, 121, 5601-5619. https://doi.org/10.1002/ 2015JD024712

Burke, C. P., \& Jones, D. L. (1992). An experimental investigation of ELF attenuation rates in the Earth-ionosphere duct Journal of Atmospheric and Terrestrial Physics, 54(3/4), 243250.

Füllekrug, M., \& Sukhorukov, A. I. (1999). The contribution of anisotropic conductivity in the ionosphere to lightning flash bearing deviations in the ELF/ULF range. Geophysical Research Letters, 26(8), 1109-1112. https://doi.org/10.1029/ 1999GL900174 
Füllekrug, M., \& Constable, S. (2000). Global triangulation of intense lightning discharges. Geophysical Research Letters, 27(3), 333-336. https://doi.org/10.1029/1999GL003684

Füllekrug, M., Reising, S. C., \& Lyons, W. A. (1996). On the accuracy of arrival azimuth determination of spriteassociated lightning flashes by Earth-ionosphere cavity resonances. Geophysical Research Letters, 23(25), 3691-3694. https://doi.org/10.1029/96GL03538

Greifinger, C., \& Greifinger, P. (1978). Approximate method for determine ELF eigenvalues in the Earth-ionosphere waveguide. Radio Science, 13, 831-837.

Koloskov, A. V., \& Yampolsky, Yu. M. (2009). Observations of radiation from North American power mains in Antarctica. Radiophysics and Radioastronomy, 14 (4), 367-376. (In Russian)

Koloskov, A. V., Budanov, O. V., Bezrodny, V. G., \& Yampolsky, Yu. M. (2004). Location of superpowerful lightning flashes through polarization magnetic measurements in Schumann resonance waveband. Radiofizika i Radioastronomiya, 9(4), 391-403. (In Russian)

Krider, E. P., Noggle, R. C., \& Uman, M. A. (1976). A gated, wideband magnetic direction finder for lightning return strokes. Journal of Applied Meteorology, 15 (3), 301-306. https:// doi.org/10.1175/1520-0450(1976)015<0301:AGWMDF> 2.0.CO;2

Litvinenko, L. N., \& Yampolsky, Yu. M. (Eds). (2005). Electromagnitnye proyavleniya geofizicheskikh effectov $v$ Antarktike [Electromagnetic manifestations of geophysical effects in Antarctica]. Institute of Radio Astronomy. (In Russian)

Mlynarczyk, J., Kulak, A., \& Salvador, J. (2017).The accuracy of radio direction finding in the extremely low frequency range. Radio Science, 52(10), 1245-1252. https:// doi.org/10.1002/2017RS006370

Nickolaenko, A. P., \& Hayakawa, M. (2002). Resonances in the Earth-ionosphere cavity. Kluwer Academic Publ.

Nickolaenko, A. P., \& Sentman, D. D. (2007). Line splitting in the Schumann resonance oscillations. Radio Science, 42(2), RS2S13. https://doi.org/10.1029 / 2006RS003473

Nickolaenko, A. P., Rabinowicz, L. M., Shvets, A. V., \& Schekotov, A. Yu. (2003). Detection of Splitting of Schumann Resonance Eigenfrequencies. Telecommunications and Radio Engineering, 60, 99-106. https://doi.org/10.1615/TelecomRadEng.v60.i1012.110

Nickolaenko, A. P., Rabinovich, L. M., Shvets, A. V., \& Shchekotov, A. Yu. (2004). Polarization characteristics of lowfrequency resonances in the Earth-ionosphere cavity. Radiophysics and Quantum Electronics, 47(4), 238-259. https:// doi.org/10.1023/B:RAQE.0000041231.22225.d5

Nickolaenko, A. P., Galuk, Y. P., \& Hayakawa, M. (2018). Source bearing of Extremely Low Frequency (ELF) waves in the Earth-ionosphere cavity with day-night nonuniformity. Journal of Geophysical Research: Atmospheres, 123(19), 10895 10910. https://doi.org/10.1029/2018JD028951
Ogawa, T., \& Tanaka, Y. (1970). Effective height of the ball antenna for measuring ELF radio signals. Special Contributions of the Geophysical Institute, Kyoto University. 10, 29-34, http://hdl.handle.net/2433/178585

Pechony, O., \& Price, C. (2004). Schumann resonance parameters calculated with a partially uniform knee model on Earth, Venus, Mars, and Titan. Radio Science, 39(5), RS5007. https://doi.org/10.1029/2004RS003056

Pechony, O., Price, C., \& Nickolaenko, A. P. (2007). Relative importance of the day-night asymmetry in Schumann resonance amplitude records. Radio Science, 42(2), RS2S06. https://doi.org/10.1029/2006RS003456

Pessi, A. T., Businger, S., Cummins, K. L., Demetriades, N. W. S., Murphy, M., \& Pifer, B. (2009). Development of a Long-Range Lightning Detection Network for the Pacific: Construction, Calibration, and Performance. Journal of Atmospheric and Oceanic Technology, 26(2), 145-166. https:// doi.org/10.1175/2008JTECHA1132.1

Sato, M., \& Fukunishi, H. (2003). Global sprite occurrence locations and rates derived from triangulation of transient Schumann resonance events. Geophysical Research Letters, 30(16), 1859. https://doi.org/10.1029/2003GL017291

Sato, M., Takahashi, Y., Yoshida, A., \& Adachi, T. (2008). Global distribution of intense lightning discharges and their seasonal variations. Journal of Physics D: Applied Physics, 41 (23), 234011. http://doi.org/10.1088/0022-3727/ $41 / 23 / 234011$

Shvets, A. V., Ivanov, V. K., \& Varavin, A. V. (2003). A Mobile Multichannel System for the Automatic Low-Frequency Signal Acquisition and Analysis in the Presence of High-Power Power-Main Noises. Instruments and Experimental Techniques, 46 (3), 351-356. https://doi.org/10.1023/A:1024462 304875

Shvets, A. V., Nickolaenko, A. P., Koloskov, A. V., Yampolsky, Yu. M., Budanov, O. V., \& Shvets, A. A. (2019). Low frequency (ELF-VLF) radio atmospherics study at the Ukrainian Antarctic Akademik Vernadsky station. Ukrainian Antarctic Journal, 1(18), 116-127. https://doi.org/10.33275/17277485.1(18).2019.136

Yang, H., \& Pasko, V. P. (2005). Three-dimensional finite-difference time domain modeling of the Earth-ionosphere cavity resonances. Geophysical Research Letters, 32(3), L03114.

Yatsevich, E. I., Shvets, A. V., \& Nickolaenko, A. P. (2014). Impact of the ELF receiver on characteristics of the observed Q-bursts. Radiophysics and Quantum Electronics, 57(3), 176186. https://doi.org/10.1007/s11141-014-9502-0

Received: 3 October 2021 Accepted: 12 December 2021 
А. Швець ${ }^{1}$, О. Буданов ${ }^{2}$, О. Колосков ${ }^{2,3}$, О. Ніколаєнко ${ }^{1}$, О. Швець ${ }^{1, *}$, Ю. Ямпольський ${ }^{2}$

${ }^{1}$ Інститут радіофізики та електроніки ім. О.Я. Усикова НАН України, м. Харків, 61085, Україна

${ }^{2}$ Радіоастрономічний інститут НАН України, м. Харків, 61002, Україна

3 Державна установа Національний антарктичний науковий центр МОН України, м. Київ, 01601, Україна

* Автор для кореспонденції: lxndrshvts9@gmail.com

\section{Оцінка похибок пеленгації потужних розрядів блискавок за вимірюваннями ННЧ-сплесків}

Анотація. У цій роботі досліджено варіації похибок при визначенні азимуту джерел ННЧ-сплесків в добовому масштабі часу. ННЧ-сплески - це електромагнітне імпульсне випромінювання в діапазоні надзвичайно низьких частот (ННЧ), яке збуджується потужними розрядами блискавок, і використовуються для виявлення блискавок по всьому світу. Оцінено похибки за даними для двох горизонтальних ортогональних компонент магнітного поля ННЧ-сплесків. Експериментальні записи ННЧ-сплесків були зроблені на станції «Академік Вернадський» в період з березня по квітень 2019 року, який охоплює день весняного рівнодення. Визначається азимут джерела ННЧ-сплеску цифровим обертанням системи координат до тих пір, поки сигнал в одній магнітній компоненті не впаде до мінімального значення. Абсолютне значення азимутальної похибки оцінювалося по відношенню амплітуди ННЧ-сплеску до стандартного відхилення залишкового сигналу. За допомогою автоматизованої процедури обробки проаналізовано понад 800 тисяч ННЧ-сплесків з амплітудою понад 10 пТл. В оцінених варіаціях помилок азимуту була виявлена характерна добова закономірність. Нічний рівень азимутальної похибки перевищував денний в середньому приблизно на два градуси. Були ідентифіковані И-подібне коливання: зменшення-підйом-зменшення при переході від ночі до дня і дзеркально-симетричне N-подібне коливання при переході від дня до ночі. Кожне з цих перехідних коливань займає близько чотирьох годин. Порівняння добових змін загальної інтенсивності фонового ННЧ шуму з діаграмами добових похибок азимуту демонструє протилежний характер: максимальний рівень фонового шуму ННЧ спостерігався в денний час, в той час як оціночні похибки азимуту в цей час приймають мінімальні значення. Це суперечить загальноприйнятому уявленню про те, що збільшення шуму збільшує похибку. Таким чином, припускаємо, що залишкова магнітна складова в ННЧ-сплеску виникає не тільки через фоновий шум, але також може бути результатом нелінійної поляризації падаючої хвилі через гіротропію нічної нижньої іоносфери. Когерентні хвилі, що виникають в результаті дифракції падаючого поля на межі розділу день-ніч в порожнині земля-іоносфера, можуть пояснити И- та N-подібні коливання азимутальної похибки під час проходження сонячного термінатора.

Ключові слова: локація блискавки, наднизькі частоти, ННЧ-сплеск, хвилевід Земля-іоносфера 